\title{
Growth and Instability Analysis of Area, Production and Yield of Major Cereals in Chhattisgarh Plains Zone of Chhattisgarh
}

\author{
Akhilesh Kumar Gupta*, Chinmayee Patra, Ravi Ranjan Kumar and Mamata \\ Department of Agricultural Statistics, Institute of Agriculture, Visva Bharati, \\ Shantiniketan, West Bengal, India \\ *Corresponding author
}

\section{Keywords}

Growth, Instability, Kinked growth model, Cereals, Chhattisgarh

Article Info

\section{Accepted:}

04 November 2019

Available Online:

10 December 2019

\section{A B S T R A C T}

This study is an attempt to analyze the performance of agriculture in Chhattisgarh plains zone of Chhattisgarh by growth and stability analysis of major cereals grown in the zone. For comparative study of before and after formation of Chhattisgarh State, the whole time series data was divided into two sub-periods and checked if there is any significance of this on the agricultural production of zone. Growth analysis was done using the kinked growth rate formula which was given by Boyce (1987) and the same method with slight modification was used for instability analysis also. The results of growth analysis have shown rising trend in production and yield for most crops during the second sub-period and instability analysis indicated declining trend in instability of production and yield during second sub-period. The relationship between growth and instability was found to be negative during the second sub-period. The analysis was done using the "R".

\section{Introduction}

Chhattisgarh is a State carved out of erstwhile Madhya Pradesh from Central India in the year 2000. It is the 10th largest State in India with a geographical area of 13,790 thousand ha. with net sown area of 4677 thousand ha. The Chhattisgarh State has been divided into 03 agro-climatic zones viz. Chhattisgarh
Plains, Bastar Plateau and Northern Hills based on the different Agro-Climatic factors i.e. rainfall, soil and availability of irrigation. The geographical area covered by Chhattisgarh Plains, Bastar Plateau and Northern Hills are 50\%, 29\% and 21.0\% respectively. Chhattisgarh plains agro climatic zone consists of 15 districts According to village papers the net sown area of this agro- 
climatic zone is 3295 thousand ha, which is $68.49 \%$ of the total geographical area of the State. Chhattisgarh is an important state for national food security as it contributed about 2.65 per cent of the total annual food grains Production in India during 2015-16 (Directorate of Economics \& Statistics, DAC\&FW). In Chhattisgarh, Rice is the foremost crop grown in about 36 lakh ha. area in kharif season which accounts for about $77 \%$ of net sown area. Only $27 \%$ of this area is irrigated and the rest is rainfed (Singh, 2018). There are many other cereal crops like Maize, Wheat, Jowar \& Kodo-Kutki (coarse cereals), which are grown in Chhattisgarh and play a vital role in food security and economics of the state.

Agricultural growth is one of the most important subjects in India as the agriculture provides the employment to more than half of the population of country. It is well known that fact weather, particularly rainfall, plays an important role in Indian agriculture since around 70 per cent of the cultivated area is dependent on rainfall and the dry land technology which is being developed in the research stations is yet to reach the fields on any significant scale (Mahendradev, 1987). Indian agriculture has grown significantly in terms of production from the past with the advent of modern technology and liberalization but there have been fluctuations in agricultural production rendering an intense debate on agricultural growth and instability in India since it has direct implications for food supply management and macroeconomic stability (Chand and Raju, 2009). An analysis of fluctuations in food grains production, apart from growth, is of greater importance for understanding the nature of food security at the regional level (Mahendradev, 1987). While there is an obvious need for agricultural growth, the increased instability in production instills more uncertainty about sustainability of agricultural growth in India. Increased instability in agriculture augments the risks involved in farm production and adversely affects farmers' income and decisions to adopt modern technologies and make investments in farming. Instability in production affects price stability and the consumers, and it increases vulnerability of low-income households to market (Chand and Raju, 2009).

A number of attempts have been made to analyze the growth and instability of various food grains at national and state level by different researchers. Mahendra Dev (1987) analysed weather adjusted and unadjusted growth rate in food grain output for all major states in the country and concluded that there is decline in instability during the post green revolution. Chand and Raju (2009) have concluded that instability has declined during the post-green revolution period. Some studies (Hazell, 1982; Rao et al., 1988; Larson et al., 2004) have concluded that instability has increased in Indian agriculture during postgreen revolution period due to adoption of modern technology.

\section{Materials and Methods}

The study has used time-series secondary data on area, production and yield for major crops, viz., Rice, Wheat, Maize, Kodo-Kutki and total food grains at the aggregate level of Chhattisgarh plains zone. The data for a period of thirty eight years, from 1980 to 2017 were collected from various issues of publications, such as "Agricultural Statistics", published by the Directorate of Agriculture, Government of M.P., Bhopal (1980-81 to 1997-1998) and rest from the director and website of Agriculture department of Chhattisgarh (www.agridept.cg.gov.in).

\section{Growth rate}

The growth rate of yield, area and production of crops is calculated by using the method of 
kinked growth rate formula. It is an improved and alternative growth rate model when there are break-points in time series-data and different sub-periods. In the case of single break-point, the kink growth model can be written as Equation (1):

$\ln Y_{t}=a+b_{1}\left(D_{1} t+D_{2} k\right)+b_{2}\left(D_{2} t-D_{2} k\right)+u_{t}$ ...(1)

where, $Y$ is the concerned variable (area, yield and production) for which the growth rate is being calculated; ' $a$ ' is the common intercept at the breakpoint between the two periods; $D_{1}$ is a dummy variable that takes the value 1 in the first sub-period and 0 in the second subperiod; $D_{2}$ is a dummy variable that takes the value 1 in the second sub-period and 0 in the first sub-period; $\mathrm{k}$ is break-point of time series and $b_{1}$ and $b_{2}$ are the growth rates during first and second sub-periods, respectively. So the elimination of discontinuity between subperiods provides a superior basis for comparison of sub-period growth rates (Boyce, 1987).

As quoted above, the Chhattisgarh State was formed in 2000 which makes a good basis to break the time series data into two sub periods and access its impact on the agriculture of Chhattisgarh plains zone by comparing the growth rates of two sub-periods. The first subperiod consists of 20 years from 1980 to 1999 while second sub-period consists of 18 years from 2000 to 2017. If $b_{2}>b_{1}$, then there would be an upward shift during post formation of State period and if $b_{1}>b_{2}$, then this shift would be downward.

\section{Measuring instability}

The instability of area, yield and production of selected crops was measured by using the Boyce method (1987) which was modified slightly to measure the instability accurately1. From Equation (1), the proportionate of residuals $Z_{t}$ can be regressed on time in the same way that growth rate was calculated and the equation can be written as:

$Z_{t}=a+b_{1}\left(D_{1} t+D_{2} k\right)+b_{2}\left(D_{2} t-D_{2} k\right)+u t \ldots$ (2)

where $Z_{t}$ is the whole square of the difference between actual and predicted values (area, production and yield) expressed as proportionate of predicted values. In notations it is expressed as:

$Z t=\left[\frac{\left(y_{t}-\hat{y}_{t}\right)}{\hat{y}_{t}}\right]^{2}$

The advantage of this method is that it gives the scope for a comparison of magnitude of instability when there are several sub-periods. This equation was used to measure instability. Similar method was used by Patalsingh and Goyari, 2013.

\section{Results and Discussion}

Growth rates of area, production and yield of major crops and total cereals

The growth rates of area, production and yield of major crops in Chhattisgarh plains zone for first and second sub period, analyzed by the kink exponential growth rate model as given by equation (1), are given in Table 1 . The results of growth rate of area revealed that only rice has significant positive growth rate in both the sub periods. The growth rate of area of other cereals (except rice) and total cereals are negative in first sub period. The areas of maize and jowar \& kodo-kutki are declining very significantly in first sub-period. The results in second sub-period revealed that only jowar and kodo-kutki has significant negative growth rate while total cereals experienced significant positive growth rates; wheat and maize experienced positive growth rates but not significant. 
The results of growth rate of production has shown that rice and total cereals had significant positive growth rates and wheat has positive but not significant growth rate while jowar \& kodo-kutki and maize has significant negative growth rates during first sub-period. During the second sub-period only jowar \& kodo-kutki has significant negative growth rate while rice, wheat maize and totals cereals experienced significant positive growth rate in production.

The results of growth rate of yield revealed that maize and jowar \& kodo-kutki had slightly positive growth rate while rice, wheat and total cereals has significant growth rates during first sub-period. During the second sub-period all crops has significant positive growth rate except jowar \& kodo- kutki. There is no crop which experienced negative growth rate in yield during any sub-period.

Instability of area, production and yield of major crops and total cereals

The estimates of instability in area, production and yield of all the studied crops estimated by applying the alternative approach by modifying Boyce (1987) method which is given in equation (2) are presented in Table 2. The instability in crop area during first subperiod has depicted a rising trend in rice, wheat and maize in which only wheat is significant while jowar \& kodo-kutki and total cereals shown not significant declining trend. During second sub-period only wheat has experienced negative trend but not significant.

The instability of maize and jowar \& kodokutki has risen very significantly, total cereals also has significant rise in instability during second sub-period also rice has positive trend in instability but not significant. In production, during first sub period all the crops have experienced positive trend in instability but it is significant only in the case of wheat. During the second sub-period only maize has experienced rising trend in instability while all other crops have experienced declining trend but none is significant.

The yield almost follows the pattern of instability in production. During first subperiod all the crops shown rising trend but none is significant. During the second subperiod only jowar \& kodo-kutki is showing positive trend in instability while other are showing declining trend in which only wheat is significant.

\section{Linkage between growth and instability}

There have been given different results regarding linkage between growth and instability by different researchers. Hazell (1982) reported that there is a positive relationship between them. Contradicting this, Mahendradev (1987) has reported a negative relationship between them for the major states of India. Patalsingh and Goyari (2013) reported negative relation relationship between them for agriculture in Odisha. We made an attempt to test that hypothesis for Chhattisgarh plains zone. The cross-sectional regression estimates between changes in instability (INST) and growth rates (CGR) were estimated for area, production and yield for the crops taken in study in both the subperiods. The results for area, production and yield in both the sub-periods are given in Table 3.

The results in Table 3 revealed that there is negative relationship between growth and instability in second sub-period but the results in first sub-period are mixed as growth and instability showing positive relationship for area and production while negative for Yield. 
Table.1 Discontinuous kinked exponential growth rates of area, production and yield of major crops of Chhattisgarh plains zone

\begin{tabular}{|c|c|c|c|c|c|c|}
\hline \multirow{2}{*}{ Crop } & \multicolumn{2}{|c|}{ Area } & \multicolumn{2}{c|}{ Production } & \multicolumn{2}{c|}{ Yield } \\
\cline { 2 - 7 } & $\mathbf{1 9 8 0 - 1 9 9 9 9}$ & $\mathbf{2 0 0 0 - 2 0 1 7}$ & $\mathbf{1 9 8 0 - 1 9 9 9 9}$ & $\mathbf{2 0 0 0 - 2 0 1 7}$ & $\begin{array}{c}\mathbf{1 9 8 0}- \\
\mathbf{1 9 9 9 9}\end{array}$ & $\mathbf{2 0 0 0 - 2 0 1 7}$ \\
\hline Rice & $0.003913^{*}$ & $0.003722^{*}$ & $0.019168^{*}$ & $0.030998^{* *}$ & $0.015255^{\prime}$ & $0.027276^{* *}$ \\
\hline Wheat & -0.005317 & 0.006027 & 0.01018 & $0.03226^{*}$ & $0.015498^{* *}$ & $0.026235^{* * *}$ \\
\hline Maize & $-0.021167^{* * *}$ & 0.004871 & $-0.01859^{\prime}$ & $0.02847^{*}$ & 0.002578 & $0.023602^{* *}$ \\
\hline $\begin{array}{c}\text { Jowar \& Kodo- } \\
\text { Kutki }\end{array}$ & $-0.047512^{* * *}$ & $-0.105087^{* * *}$ & - & - & 0.009451 & 0.004035 \\
\hline Total Cereals & -0.001364 & $0.003856^{\prime}$ & $0.017047^{\prime}$ & $0.033018^{* * *}$ & $0.018411^{*}$ & $0.029162^{* *}$ \\
\hline
\end{tabular}

', *, ** and $* * *$ indicate significance at $10 \%, 5 \%, 1 \%$ and $0.1 \%$ levels respectively.

Table.2 Instability in area, production and yield of major crops of Chhattisgarh plains zone

\begin{tabular}{|c|c|c|c|c|c|c|}
\hline \multirow[t]{2}{*}{ Crop } & \multicolumn{2}{|c|}{ Area } & \multicolumn{2}{|c|}{ Production } & \multicolumn{2}{|c|}{ Yield } \\
\hline & 1980-19999 & $2000-2017$ & $\begin{array}{l}1980- \\
19999\end{array}$ & $2000-2017$ & $\begin{array}{l}1980- \\
19999\end{array}$ & 2000-2017 \\
\hline Rice & 0.00003962 & 0.0003718 & 0.0006937 & -0.001831 & 0.0002815 & -0.0019997 \\
\hline Wheat & $0.015465^{\prime}$ & -0.010455 & $0.02972^{\prime}$ & -0.02217 & 0.000186 & $-0.0014952^{\prime}$ \\
\hline Maize & 0.0005595 & $0.0029083^{* *}$ & 0.003061 & 0.002821 & 0.001555 & -0.001999 \\
\hline $\begin{array}{c}\text { Jowar \& } \\
\text { Kodo-Kutki }\end{array}$ & -0.0001588 & $0.0040799 * * *$ & 0.0002922 & -0.000661 & 0.0002214 & 0.0034722 \\
\hline $\begin{array}{c}\text { Total } \\
\text { Cereals }\end{array}$ & 0.00001019 & $0.0008565^{\prime}$ & 0.00136 & -0.00211 & 0.001163 & -0.002949 \\
\hline
\end{tabular}

, *, ** and $* * *$ indicate significance at $10 \%, 5 \%, 1 \%$ and $0.1 \%$ levels respectively.

Table.3 Regression models between Growth and Instability

\begin{tabular}{|c|c|c|}
\hline $\begin{array}{c}\text { Production } \\
\text { Parameters }\end{array}$ & $\mathbf{1 9 8 0 - 1 9 9 9}$ & $\mathbf{2 0 0 0 - 2 0 1 7}$ \\
\hline Area & INST $=0.0043+0.081 \mathrm{CGR}$ & INST $=-0.0014-0.053 \mathrm{CGR}$ \\
\hline production & INST $=0.0073+0.135 \mathrm{CGR}$ & INST $=-0.005-0.0415 \mathrm{CGR}$ \\
\hline Yield & INST $=0.00122-0.0441 \mathrm{CGR}$ & INST $=0.0044-0.245 * * * \mathrm{CGR}$ \\
\hline
\end{tabular}

So, it can be stated that there is negative relationship between growth and instability which indicates that when instability declines, growth rate increases and vice versa. Analyzing growth and instability of major cereal crops and total cereals of Chhattisgarh plains zone given some interesting picture. By the results of growth analysis of area, production and yield it is evident that the separate State formation of Chhattisgarh has a significant effect in the agriculture of Chhattisgarh plains zone as there is significant rising trend in growth rate of production for most of the crops except Jowar and Kodo- 
kutki during the second sub-period (i.e. after formation of Chhattisgarh State). The similar results also follows for area and yield during second sub-period. The study has revealed that most crops have rising trend of instability during first sub-period but experienced declining trend in instability in the production during the second sub-period which is good for the agriculture of Chhattisgarh plains zone. Only maize has the positive trend of instability for area and production both during second sub-period. There is evidence of increasing trend in instability in area but production and yield has experienced declining trend of instability.

\section{References}

Boyce, J.K.1987. Agrarian Impasse in Bengal: Institutional Constraints to Technological Change. Oxford University Press.

Chand, R. and Raju, S.S. 2009. Instability in Indian agriculture during different phases of technology and policy. Indian Journal of Agricultural Economics, 64(2): 187-207.
Dash, A., D.S. Dhakre and Bhattacharya, D. 2017. Analysis of Growth and Instability in Rice Production of Odisha by Fitting Appropriate Statistical Models. Int.J.Curr.Microbiol.App.Sci. $\quad$ 6(10): 3313-3322. doi: https://doi.org/10.20546/ijcmas.2017.6 10.388

Hazell, P.B.R.1982. Instability in Indian Foodgrains Production. Research Report No. 30, International Food Policy Research Institute, Washington D.C.

Mahendradev, S.1987. Growth and instability in food grains production: An interstate analysis. Economic and Political Weekly, 22(39): A82-A92.

Paltasingh, R.K., Goyari, P. 2013. Agricultural Economics Research Review. Vol. 26 (Conference number) 67-78.

Singh, R., Brahme, R., Singh, V.B. 2018. Growth in Area, Production, and Productivity of Kharif Paddy in Chhattisgarh. International Journal of Agricultural Science and Research (IJASR). Vol. 8, Issue 4, Aug 2018, 65-72.

\section{How to cite this article:}

Akhilesh Kumar Gupta, Chinmayee Patra, Ravi Ranjan Kumar and Mamata. 2019. Growth and Instability Analysis of Area, Production and Yield of Major Cereals in Chhattisgarh Plains Zone of Chhattisgarh. Int.J.Curr.Microbiol.App.Sci. 8(12): 128-133. doi: https://doi.org/10.20546/ijcmas.2019.812.020 